\title{
Spatial and temporal variability of macrobenthic communities in tidepools on a rocky shore in Nova Scotia, Canada
}

\author{
Anna Metaxas, Heather L. Hunt, Robert E. Scheibling \\ Department of Biology, Dalhousie University, Halifax, Nova Scotia, Canada B3H 4J1
}

\begin{abstract}
Spatial and temporal patterns in the distribution and abundance of macroalgae and macrofauna were measured in 4 pools in each of 3 intertidal zones (mid, high and splash) on a rocky shore near Halifax, Nova Scotia, Canada. Sheets, filamentous, coarsely branched, thick leathery, jointed calcareous, and crustose forms were the most abundant macroalgal functional groups, and mussels, littorinid snails and whelks were the most abundant macroinvertebrates in the pools. Percentage cover of the late-successional macroalgal forms, such as thick leathery and crustose forms, was greatest in the mid pools where environmental fluctuations are smaller and more predictable. Percentage cover of the more opportunistic forms, such as sheets and filamentous algae, was variable among pools in all zones, whereas percentage cover of the other functional forms was most variable among mid pools on most sampling dates. Mussels and whelks were more abundant in mid pools, whereas littorines were more abundant in the high pools. Macrofaunal abundance also was variable among pools within most zones on most sampling dates. Multiple regressions showed that grazer density, nutrient regime and physical characteristics of the tidepools can consistently explain the variability in percentage cover of late-successional macroalgal functional forms, but not of the more opportunistic forms. The horizontal spatial variability in percentage cover of macroalgae may result from differential recruitment of opportunistic forms, and/or differences in the physical characteristics of the pools which affect slow-growing, late-successional forms. The Shannon Diversity Index for the macroalgal and the macrofaunal assemblages was greatest in mid pools, suggesting that a smaller number of macroalgal and macroinvertebrate species can survive in the higher pools where conditions are harsher. Cluster analyses showed that the macroalgal assemblages were mostly similar among mid pools, and that macrofaunal assemblages of mid pools were similar to high pools, but not splash pools. Our study shows that macrobenthic community structure in tidepools does not vary consistently with the period of tidal isolation and there is large variability among pools within intertidal zones.
\end{abstract}

KEY WORDS: Community organisation - Diversity - Functional groups - Macroalgae - Macrofauna . Rocky intertidal zone $\cdot$ Tidepool $\cdot$ Spatial and temporal variability · Zonation

\section{INTRODUCTION}

Biological zonation along the intertidal gradient is a prominent feature of the emergent substrata of rocky shores around the world (Stephenson \& Stephenson 1950, 1952, 1954a, b, Dayton 1971, Lubchenco \& Menge 1978, Underwood 1981, Janke 1990). In tidepools, however, zonation patterns are less clear due to large variability in species abundance among tidepools at similar tidal heights (see Metaxas \& Scheibling 1993 for review). Nevertheless, some algal forms (e.g. Spongomorpha, fucoids and coralline algae such as Corallina) tend to be found mainly in pools located lower on the shore, whereas other forms (e.g. Enteromorpha) dominate in pools higher on the shore (Fraser 1936, Green 1971, Daniel \& Boyden 1975, GossCustard et al. 1979, Femino \& Mathieson 1980, Dethier 1982, 1984, Sze 1982, Wolfe \& Harlin 1988a, Kooistra et al. 1989). Moreover, species diversity tends to decrease in pools with increasing intertidal height (Femino \& Mathieson 1980, Huggett \& Griffiths 1986, Wolfe \& Harlin 1988b, Kooistra et al. 1989).

Variability in the biological communities has been attributed to differences in the physical characteristics of tidepools (e.g. area, volume and depth) which provide a greater range of physical settings than the emer- 
gent substrata (Johnson \& Skutch 1928, Droop 1953, Marsh et al. 1978, Bennett \& Griffiths 1984, Fairweather \& Underwood 1991). Also, because a number of factors determine the extent of tidal exchange into the pools (e.g. orientation, wave exposure, height of the surrounding rocks, and drainage patterns) vertical distance above chart datum probably does not sufficiently describe the tidal position of a tidepool. Tidepools separated by a small vertical distance may receive different tidal inputs and thus harbour different biological communities. Because of the large variability in their algal communities, tidepools are often characterized by the dominant algal groups rather than their height on the shore, in contrast to the communities on emergent substrata (e.g. Stephenson et al. 1934, Gustavsson 1972, Sze 1982).

In this study, we examine spatial and temporal patterns in the distribution and abundance of macroalgal and macrofaunal communities of tidepools across an intertidal gradient on a rocky shore in Nova Scotia. We compare the spatial variability of these communities among pools within the same intertidal zone to spatial variability among zones, over a period of $15 \mathrm{mo}$. We also examine the relationship between macroalgal abundance patterns and various biological and physical characteristics of the tidepools. In order to examine processes responsible for community organization in any system, the potential sources of variability for that system should be described. Our study provides a basis for assessing existing hypotheses (and generating new ones) to account for the large variability in macrobenthic communities that is observed in tidepools on rocky shores.

\section{MATERIALS AND METHODS}

Four tidepools in each of 3 intertidal zones (mid, high and splash, determined by the period of isolation of the pools) were sampled at Cranberry Cove, an exposed rocky shore near Halifax, Nova Scotia, Canada ( $44^{\circ} 28^{\prime}$ $\mathrm{N}, 63^{\circ} 56^{\prime} \mathrm{W}$ ) in June, August and October 1991, and at monthly intervals between May and September 1992. The shoreline consisted of gradually sloping granite platforms and large rock outcrops (10 to $30 \%$ grade), has a southern exposure to the Atlantic Ocean and receives up to $10 \mathrm{~m}$ swells especially in the fall. The pools were irregularly shaped with the maximum dimension ranging from 2 to $14 \mathrm{~m}$ and maximum depth ranging from 0.21 to $0.75 \mathrm{~m}$. Transect lines were set at $0.5 \mathrm{~m}$ intervals along the length of each pool to either side of a central line. Length was measured along each transect line and width was measured at $0.5 \mathrm{~m}$ intervals along the central line. This provided a map of the pool perimeter which was then digitized to estimate surface area. Pool depth was measured at $0.3 \mathrm{~m}$ intervals along each of the $0.5 \mathrm{~m}$ transects, subdividing the pool into a grid of $0.5 \times 0.3 \mathrm{~m}$ subunits (units around the perimeter were smaller). Average depth within each subunit was estimated by averaging the depths at each corner, and the volume of each tidepool estimated by summing the subunit volumes. The period of isolation of each pool was determined on 17 dates (June 1990 . and at about 2 to 6 wk intervals between March 1991 and July 1992) as the period between tidal recession and subsequent tidal input, including spray. The height above chart datum of each pool was measured using a transit level in July 1991 and 1992. Flushing rate of each pool was determined as the percentage decrease in concentration of a fluorescent red dye (Rhodamine B, Sigma ${ }^{\oplus}$ chemicals), added to the pools in known concentration, over the period between slack low and high tides (i.e. per tidal cycle). Flushing rate was measured on 9 July 1992, when wave height was between 2 and $3 \mathrm{~m}$ and it was raining lightly, and on 30 August 1993 when wave height was ca $1 \mathrm{~m}$ and it was not raining.

In June, August and October 1991, and May and June 1992, two $60 \mathrm{ml}$ samples were collected at mid-depth of each pool for nutrient analysis with an acid-washed $(1 \mathrm{~N} \mathrm{HCl})$ syringe. These samples were pressure-filtered through a $0.8 \mu \mathrm{m}$ Millipore ${ }^{\oplus}$ filter and frozen for subsequent analysis. Nitrate and phosphate concentrations were measured with a Technicon AA2 autoanalyzer and ammonium concentration was determined spectrophotometrically according to Parsons et al. (1984).

In each tidepool, percentage cover of the upper visible layer of macroalgae and macrofaunal density was measured in five $0.2 \times 0.2 \mathrm{~m}$ quadrats (except for littorinid abundance which was measured in five $0.1 \times$ $0.1 \mathrm{~m}$ quadrats). The quadrats were randomly assigned for each sampling date. Percentage cover of macroalgae was estimated by placing a plastic quadrat with 60 randomly placed holes on the substratum and counting the number of holes overlying each species.

Macroalgae were assigned to each of the functional/form groups suggested by Littler (1980) and Littler \& Littler $(1980,1984)$ : sheets, filamentous, coarsely branched, thick leathery, jointed calcareous and crustose forms. Macrofauna consisted mainly of mussels (Mytilus edulis and/or M. trossulus), littorines (Littorina littorea, L. obtusata and L. rudis) and whelks (Nucella lapillus). For each sampling date, abundances of each macroalgal and macrofaunal species or group, as well as the cover of bare rock, were compared among intertidal zones, and among pools within zones, using 2 -factor analyses of variance. The effect of the nested factor (pool) was examined within each zone (mid, high and splash). 
Backwards elimination stepwise multiple regressions (Sokal \& Rohlf 1981, Kleinbaum et al. 1988) were done to examine the relationship of each macroalgal functional group with littorine and mussel abundance, the physical characteristics of the pools (height above chart datum, flushing rate, volume and surface area) and the nutrient regime (nitrate + nitrite, phosphate and ammonium concentrations and the nitrogen to phosphorus ratio). Regressions were carried out for the entire sampling period and for each sampling date. The $\alpha$-to-remove value was 0.150 .

We examined spatial and temporal variability in the macroalgal and macrofaunal assemblages of the tidepools in 2 ways. Firstly, the Shannon Diversity Index $\left(H^{\prime}\right)$ (Pielou 1969) was calculated separately for macroalgae and macrofauna for each tidepool and each sampling date as $H^{\prime}=\sum_{i=1}^{n} P_{1} \ln P_{i}$, where $P_{1}$ is the proportion of the $i$ th species in each tidepool. Comparisons of $H^{\prime}$ among intertidal zones for the entire sampling period were done using 2 -factor analyses of variance (zone and date). Secondly, we used the Bray Curtis measure of dissimilarity (Field et al. 1982), calculated separately for macroalgae and macrofauna, in a cluster analysis by average linkage of pools at each sampling date.

For all statistical analyses, macroalgal percentage cover was arcsine $(\sqrt{x})$-transformed and macrofaunal density was $\ln (x+1)$-transformed to successfully remove heterogeneity of variance when detected using Cochran's test. A posteriori multiple comparisons of treatment means were done using Student-NewmanKeuls (SNK) tests. All analyses were carried out using SYSTAT v. 5.1 (Wilkinson 1989) on a Macintosh SE 30 computer.

\section{RESULTS}

\section{Physical and chemical environment}

The physical characterstics of the tidepools at Cranberry Cove are summarized in Table 1. Pools with 3 to $8 \mathrm{~h}$ average periods of isolation over the 17 sampling dates were assigned to the mid zone, those with 10 to $12 \mathrm{~h}$ periods to the high zone, and those that were not reached by splash on most dates, or received tidal input only during storms, were assigned to the splash zone.

Nutrient concentrations were highly variable among pools within zones and no general trends were apparent in nutrient concentration among zones (Table 2). Nitrate + nitrite concentrations were greatest in the high zone in August 1991 and May 1992, whereas the concentrations of phosphate and ammonium were similar on all sampling dates. None of the nutrients varied significantly among zones on any sampling date (in all cases $F_{2,9}<4.26, \mathrm{p}>0.05$ ).

\section{Temporal patterns of abundance}

Most functional groups of macroalgae (Table 3) were present on more than one sampling date in the tidepools (Figs. 1, 2, $3 \& 4$ ). Sheets were present in all pools in all zones (mainly Enteromorpha intestinalis and Scytosiphon lomentarial and their percentage cover, averaged over all pools, was highest in May and June of both years (Fig. 1). Filamentous forms (mainly Cladophora spp. and Spongomorpha spp.) also were present in most pools on most dates and their cover decreased with the increase in cover of

Table 1. Physical characteristics of 12 tidepools located in 3 intertidal zones (mid, high and splash), at Cranberry Cove, Nova Scotia, Canada. CD: chart datum; -: no input during tidal cycle

\begin{tabular}{|c|c|c|c|c|c|c|c|}
\hline \multirow{2}{*}{$\begin{array}{l}\text { Intertidal } \\
\text { zone }\end{array}$} & \multirow{2}{*}{$\begin{array}{l}\text { Surface } \\
\text { area }\left(\mathrm{m}^{2}\right)\end{array}$} & \multirow{2}{*}{$\begin{array}{l}\text { Maximum } \\
\text { depth }(\mathrm{m})\end{array}$} & \multirow{2}{*}{$\begin{array}{l}\text { Volume } \\
\qquad\left(\mathrm{m}^{3}\right)\end{array}$} & \multirow{2}{*}{$\begin{array}{l}\text { Isolation } \\
\text { period (h) }\end{array}$} & \multirow{2}{*}{$\begin{array}{l}\text { Height above } \\
\text { CD (m) }\end{array}$} & \multicolumn{2}{|c|}{ Flushing rate $(\%)$} \\
\hline & & & & & & July 1992 & August 1993 \\
\hline \multicolumn{8}{|l|}{ Mid zone } \\
\hline Pool 1 & 3.20 & 0.147 & 0.19 & 3 & 1.2 & 100 & 100 \\
\hline Pool 2 & 10.91 & 0.448 & 2.03 & 5 & 1.4 & 100 & 100 \\
\hline Pool 3 & 14.36 & 0.357 & 1.81 & 7 & 2.3 & 75 & 94 \\
\hline Pool 4 & 8.94 & 0.460 & 2.27 & 8 & 1.2 & 37 & 48 \\
\hline \multicolumn{8}{|l|}{ High zone } \\
\hline Pool 1 & 10.04 & 0.188 & 0.92 & 12 & 3.0 & 15 & 21 \\
\hline Pool 2 & 15.75 & 0.266 & 1.49 & 11 & 2.5 & 66 & 99 \\
\hline Pool 3 & 24.23 & 0.641 & 7.28 & 12 & 2.6 & 23 & 0 \\
\hline Pool 4 & 11.84 & 0.134 & 0.68 & 10 & 2.9 & 40 & 8 \\
\hline \multicolumn{8}{|c|}{ Splash zone } \\
\hline Pool 1 & 0.68 & 0.131 & 0.05 & - & 2.8 & 0 & 11 \\
\hline Pool 2 & 8.85 & 0.308 & 1.15 & - & 3.4 & 37 & 4 \\
\hline Pool 3 & 7.47 & 0.320 & 0.71 & - & 3.9 & 36 & 7 \\
\hline Pool 4 & 3.94 & 0.425 & 0.94 & - & 4.5 & 52 & 0 \\
\hline
\end{tabular}


Table 2. Nutrient concentrations $(\mu \mathrm{M})$ and ratios (mean $\pm \mathrm{SD}$ ) in 4 tidepools in each of 3 intertidal zones at Cranberry Cove, Nova Scotia, Canada

\begin{tabular}{|c|c|c|c|c|c|c|}
\hline Nutrient & Zone & $\begin{array}{c}5 \text { June } \\
1991\end{array}$ & $\begin{array}{l}8 \text { August } \\
1991\end{array}$ & $\begin{array}{c}27 \text { October } \\
1991\end{array}$ & $\begin{array}{c}12 \text { May } \\
1992\end{array}$ & $\begin{array}{c}15 \text { June } \\
1992\end{array}$ \\
\hline $\mathrm{NO}_{3}+\mathrm{NO}_{2}$ & $\begin{array}{l}\text { Mid } \\
\text { High } \\
\text { Splash }\end{array}$ & $\begin{array}{l}1.10 \pm 0.41 \\
0.77 \pm 0.38 \\
1.44 \pm 0.84\end{array}$ & $\begin{array}{l}1.46 \pm 1.20 \\
4.15 \pm 6.01 \\
1.89 \pm 2.07\end{array}$ & $\begin{array}{l}1.68 \pm 2.37 \\
0.39 \pm 0.32 \\
1.03 \pm 1.46\end{array}$ & $\begin{array}{l}1.82 \pm 0.92 \\
6.75 \pm 11.94 \\
2.32 \pm 1.53\end{array}$ & $\begin{array}{l}1.75 \pm 0.67 \\
0.63 \pm 0.27 \\
2.13 \pm 3.28\end{array}$ \\
\hline $\mathrm{NH}_{4}{ }^{+}$ & $\begin{array}{l}\text { Mid } \\
\text { High } \\
\text { Splash }\end{array}$ & $\begin{array}{l}0.32 \pm 0.44 \\
0.07 \pm 0.14 \\
0.29 \pm 0.35\end{array}$ & $\begin{array}{l}0.00 \pm 0.00 \\
0.04 \pm 0.09 \\
0.31 \pm 0.62\end{array}$ & $\begin{array}{l}0.15 \pm 0.19 \\
0.17 \pm 0.31 \\
0.88 \pm 0.83\end{array}$ & $\begin{array}{l}0.00 \pm 0.00 \\
0.02 \pm 0.04 \\
0.00 \pm 0.00\end{array}$ & $\begin{array}{l}0.36 \pm 0.25 \\
0.00 \pm 0.00 \\
0.57 \pm 1.06\end{array}$ \\
\hline $\mathrm{PO}_{4}$ & $\begin{array}{l}\text { Mid } \\
\text { High } \\
\text { Splash }\end{array}$ & $\begin{array}{l}0.37 \pm 0.26 \\
0.33 \pm 0.18 \\
0.40 \pm 0.15\end{array}$ & $\begin{array}{l}0.41 \pm 0.22 \\
0.39 \pm 0.28 \\
0.53 \pm 0.39\end{array}$ & $\begin{array}{l}0.47 \pm 0.18 \\
0.51 \pm 0.26 \\
0.22 \pm 0.23\end{array}$ & $\begin{array}{l}0.52 \pm 0.27 \\
0.42 \pm 0.47 \\
0.34 \pm 0.41\end{array}$ & $\begin{array}{l}0.51 \pm 0.56 \\
0.37 \pm 0.19 \\
0.97 \pm 0.98\end{array}$ \\
\hline$N: P$ & $\begin{array}{l}\text { Mid } \\
\text { High } \\
\text { Splash }\end{array}$ & $\begin{array}{l}3.92 \pm 1.02 \\
2.41 \pm 0.40 \\
4.15 \pm 1.99\end{array}$ & $\begin{aligned} 3.26 & \pm 1.29 \\
13.74 & \pm 19.17 \\
6.15 & \pm 5.21\end{aligned}$ & $\begin{array}{l}2.32 \pm 2.19 \\
1.56 \pm 1.48 \\
8.75 \pm 7.86\end{array}$ & $\begin{array}{c}3.34 \pm 0.72 \\
9.78 \pm 10.74 \\
16.40 \pm 19.00\end{array}$ & $\begin{array}{l}6.72 \pm 2.05 \\
1.75 \pm 1.04 \\
2.71 \pm 1.55\end{array}$ \\
\hline
\end{tabular}
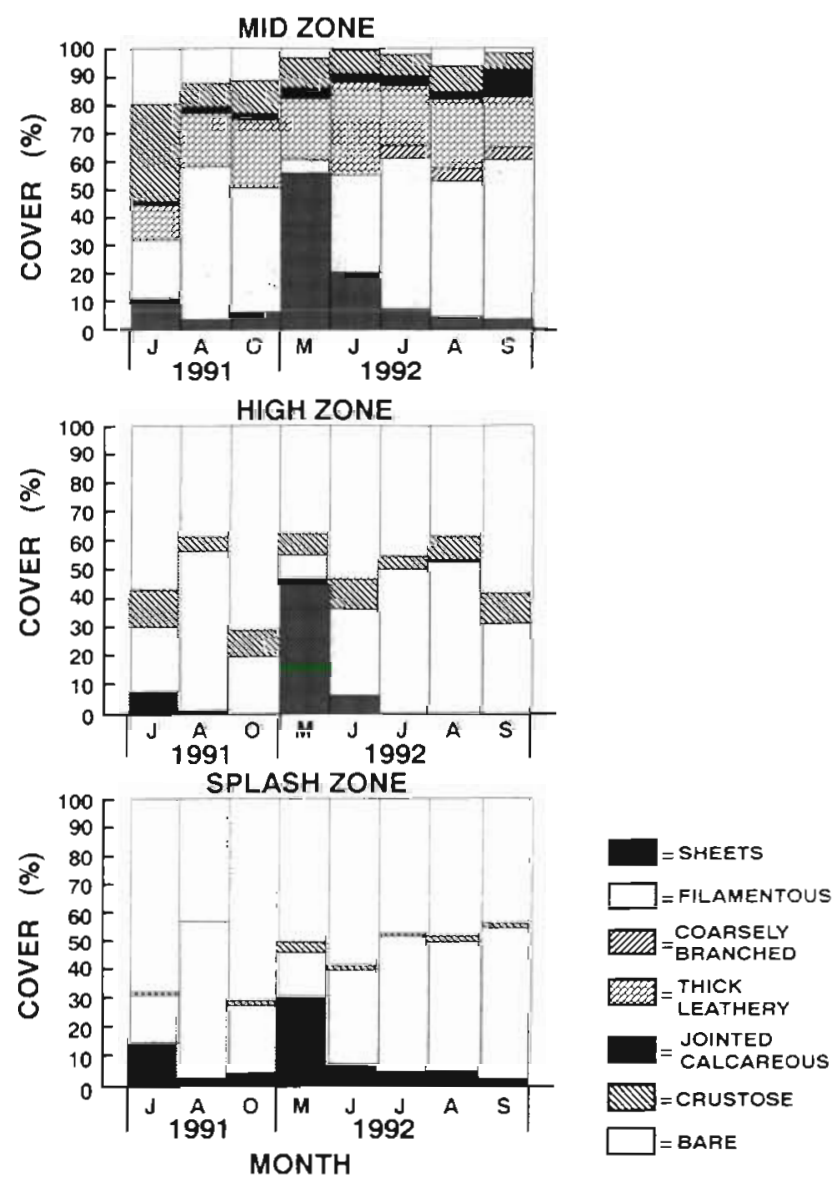

Fig. 1. Mean percentage cover of 6 functional forms of macroalgae and of bare substratum in tidepools in 3 intertidal zones (mid, high and splash) at Cranberry Cove, Nova Scotia, sampled in June, August and October 1991, and at monthly intervals between May and September $1992(n=4)$

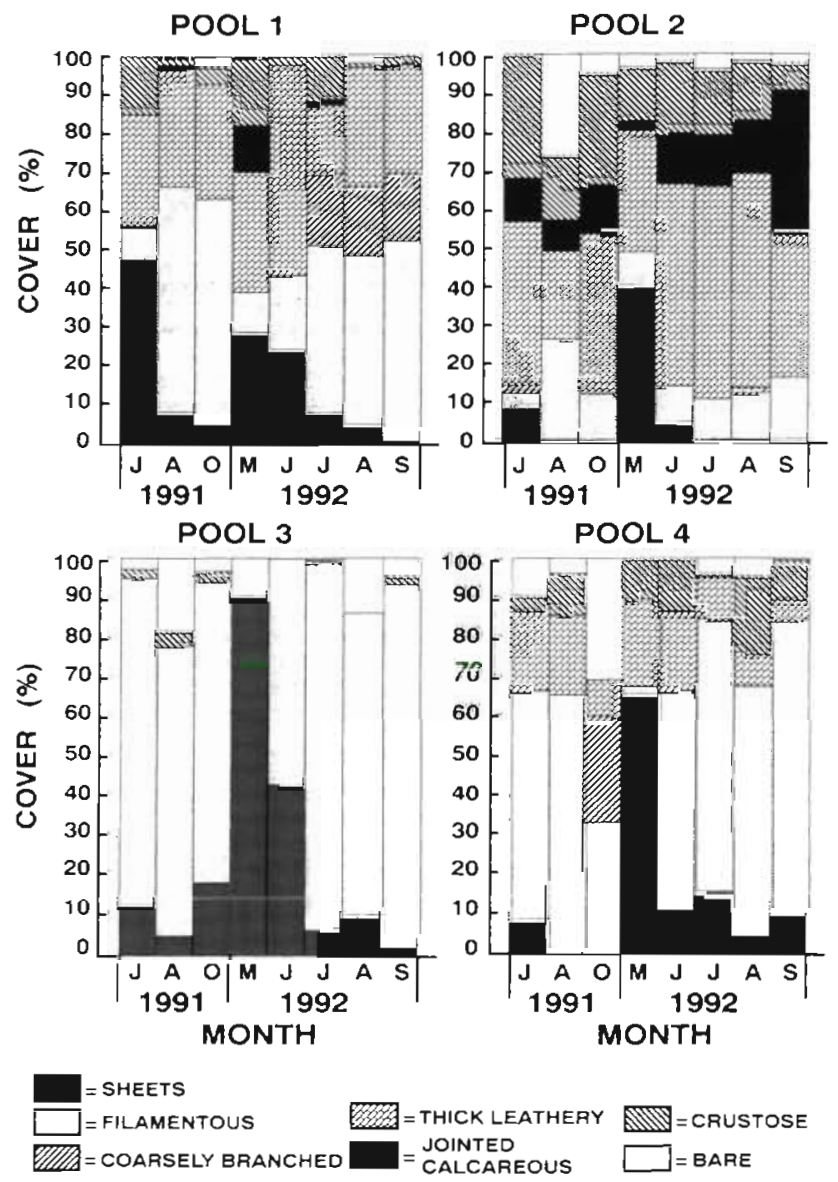

Fig. 2. Mean percentage cover of 6 functional forms of macroalgae and of bare substratum in 4 tidepools in the mid intertidal zone at Cranberry Cove, Nova Scotia, sampled in June, August and October 1991, and at monthly intervals between May and September 1992 ( $n=5$ ) 
Table 3. List of species of macroalgae and macroinvertebrates present in the tidepools on at least 1 sampling date between June 1991 and September 1992

\begin{tabular}{|c|c|c|c|c|c|c|c|c|c|c|c|c|}
\hline \multirow[t]{2}{*}{ Taxon } & \multicolumn{4}{|c|}{ Mid pools } & \multicolumn{4}{|c|}{ High pools } & \multicolumn{4}{|c|}{ Splash pools } \\
\hline & 1 & 2 & 3 & 4 & 1 & 2 & 3 & 4 & 1 & 2 & 3 & 4 \\
\hline \multicolumn{13}{|l|}{ Sheets } \\
\hline Enteromorpha intestinalis & & & $\checkmark$ & $\checkmark$ & $\checkmark$ & $\checkmark$ & $\checkmark$ & $\checkmark$ & $\checkmark$ & $\checkmark$ & $\checkmark$ & $\checkmark$ \\
\hline Petalonia fascia & $\checkmark$ & $\checkmark$ & & & & & & & & & & \\
\hline Scytosiphon lomentaria & $\checkmark$ & $\checkmark$ & $\checkmark$ & $\checkmark$ & $\checkmark$ & $\checkmark$ & $\checkmark$ & $r$ & $\checkmark$ & & & $\checkmark$ \\
\hline Ulva lactuca & $\checkmark$ & $\checkmark$ & & & & & & & & & & \\
\hline \multicolumn{13}{|l|}{ Filamentous } \\
\hline Bonnemaisonia hamifera & $\checkmark$ & & & & & & & & & & & \\
\hline Ceramium rubrum & $\checkmark$ & & & & & & & & & & & \\
\hline Chaetomorpha melagonium & $\checkmark$ & & & & & & & & & & & \\
\hline Cladophora sp. & $\checkmark$ & $\checkmark$ & $\checkmark$ & $\checkmark$ & & & & & & & & \\
\hline Ectocarpus/Pilayella spp. & $\checkmark$ & & & & & & & & & & & \\
\hline Spongomorpha sp. & $\checkmark$ & $\checkmark$ & $\checkmark$ & $\checkmark$ & $\checkmark$ & $\checkmark$ & $\checkmark$ & $\checkmark$ & & $\checkmark$ & $\checkmark$ & $\checkmark$ \\
\hline \multicolumn{13}{|l|}{ Coarsely branched } \\
\hline Chordaria flagelliformis & $\checkmark$ & $\checkmark$ & & & & & & & & & & \\
\hline Devaleraea ramentacea & $\checkmark$ & & & & & & & & & & & \\
\hline \multicolumn{13}{|l|}{ Thick leathery } \\
\hline Ascophyllum nodosum & & & & $\checkmark$ & & & & $\checkmark$ & & & & \\
\hline Fucus vesiculosus & $\checkmark$ & $\checkmark$ & & $\checkmark$ & $\checkmark$ & & & $\checkmark$ & & & & \\
\hline Laminaria digitata/L. saccharma & $\checkmark$ & $\checkmark$ & & & & & & & & & & \\
\hline Palmaria palmata & $\checkmark$ & & & & & & & & & & & \\
\hline \multicolumn{13}{|l|}{ Jointed calcareous } \\
\hline Corallina officinalis & $\checkmark$ & $\checkmark$ & & & & & $\checkmark$ & & & & & \\
\hline \multicolumn{13}{|l|}{ Crustose } \\
\hline Hildenbrandia rubra & $\checkmark$ & $\checkmark$ & $\checkmark$ & $\checkmark$ & $\checkmark$ & & $\checkmark$ & $\checkmark$ & $\checkmark$ & & $\checkmark$ & $\checkmark$ \\
\hline Phymatolithon sp. & $\checkmark$ & $\checkmark$ & $\checkmark$ & $\checkmark$ & $\checkmark$ & & $\checkmark$ & $\checkmark$ & $\checkmark$ & & & $\checkmark$ \\
\hline Ralfsia $\mathrm{sp}$ & & & & & $\checkmark$ & & & $\checkmark$ & & & & \\
\hline \multicolumn{13}{|l|}{ Mussels } \\
\hline Mytilus edulis/M. trossulus & $\checkmark$ & $\checkmark$ & $\checkmark$ & $\checkmark$ & $\checkmark$ & $\checkmark$ & $\checkmark$ & $\checkmark$ & $\checkmark$ & $\checkmark$ & $\checkmark$ & $\checkmark$ \\
\hline \multicolumn{13}{|l|}{ Littorines } \\
\hline Littorina littorea & $\checkmark$ & $\checkmark$ & $\checkmark$ & $\checkmark$ & $\checkmark$ & $\checkmark$ & $\checkmark$ & $\checkmark$ & & & & \\
\hline L. obtusata & $\checkmark$ & $\checkmark$ & $\checkmark$ & $\checkmark$ & $\checkmark$ & & $\checkmark$ & $\checkmark$ & $\checkmark$ & & $\checkmark$ & $\checkmark$ \\
\hline L. rudis & $\checkmark$ & $\checkmark$ & $\checkmark$ & $\checkmark$ & $\checkmark$ & $\checkmark$ & $\checkmark$ & $\checkmark$ & $\checkmark$ & & $\checkmark$ & $\checkmark$ \\
\hline \multicolumn{13}{|l|}{ Whelks } \\
\hline Nucella lapillus & $\checkmark$ & $\checkmark$ & $\checkmark$ & $\checkmark$ & & & $\checkmark$ & $\checkmark$ & & $\checkmark$ & $\checkmark$ & $\checkmark$ \\
\hline \multicolumn{13}{|l|}{ Anemones } \\
\hline Metridium senile & $\checkmark$ & $\checkmark$ & & & & & & & & & & \\
\hline \multicolumn{13}{|l|}{ Barnacles } \\
\hline Semibalanus balanoides & & $\checkmark$ & & & & & & & & & & \\
\hline \multicolumn{13}{|l|}{ Urchins } \\
\hline Strongylocentrotus droebachiensis & $\checkmark$ & $\checkmark$ & & & & & $\boldsymbol{v}$ & & & & & \\
\hline \multicolumn{13}{|l|}{ Limpets } \\
\hline Tectura testudinalis & $\checkmark$ & $\checkmark$ & & & & & & & & & & \\
\hline
\end{tabular}

sheets. Coarsely branched forms (mainly Chordaria flagelliformis) were rare, occuring only in mid pools between June and September (Fig. 2). Jointed calcareous forms (Corallina officinalis) were found mostly in 1 mid pool with maximal cover in September (Fig. 2). No consistent temporal changes in percentage cover of thick leathery (mainly Fucus vesiculosus) and crustose forms (mainly Phymatolithon sp. in mid pools, and Hildenbrandia rubra in high and splash pools) were observed over the sampling period. The cover of bare substratum appeared to increase in high and splash pools in June (i.e. after the decrease in sheets), and in October.

The 3 most abundant groups of macrofauna present in the pools on most sampling dates were: mytilid mussels, littorinid snails and whelks. The density of mussels was 
highly variable among pools, but tended to increase in early summer (Fig. 5). Two species of Mytilus are found in Nova Scotia, Mytilus edulis and $M$. trossulus (Pedersen 1991), although we did not differentiate these species in this study. Littorinid snails were abundant in all pools except in 1 splash pool where they were never recorded (Fig. 6). Temporal patterns in littorinid abundance were similar to those of mussels. Littorina littorea was found in mid and high pools whereas $L$. obtusata and $L$. rudis were found in all zones, with $L$. rudis being the most abundant species in high and splash pools. Whelks Nucella lapillus were abundant in 2 of the mid pools where they increased in density in summer of both years, but absent in 2 of the 4 pools in both the high and the splash zone (Fig. 7). Anemones Metridium senile, barnacles Semibalanus balanoides, limpets Tectura testudinalis and urchins Strongylocentrotus droebachiensis were recorded in a few pools on some sampling dates (mainly in 2 mid pools in summer), but were not included in any statistical analysis because of their rarity.
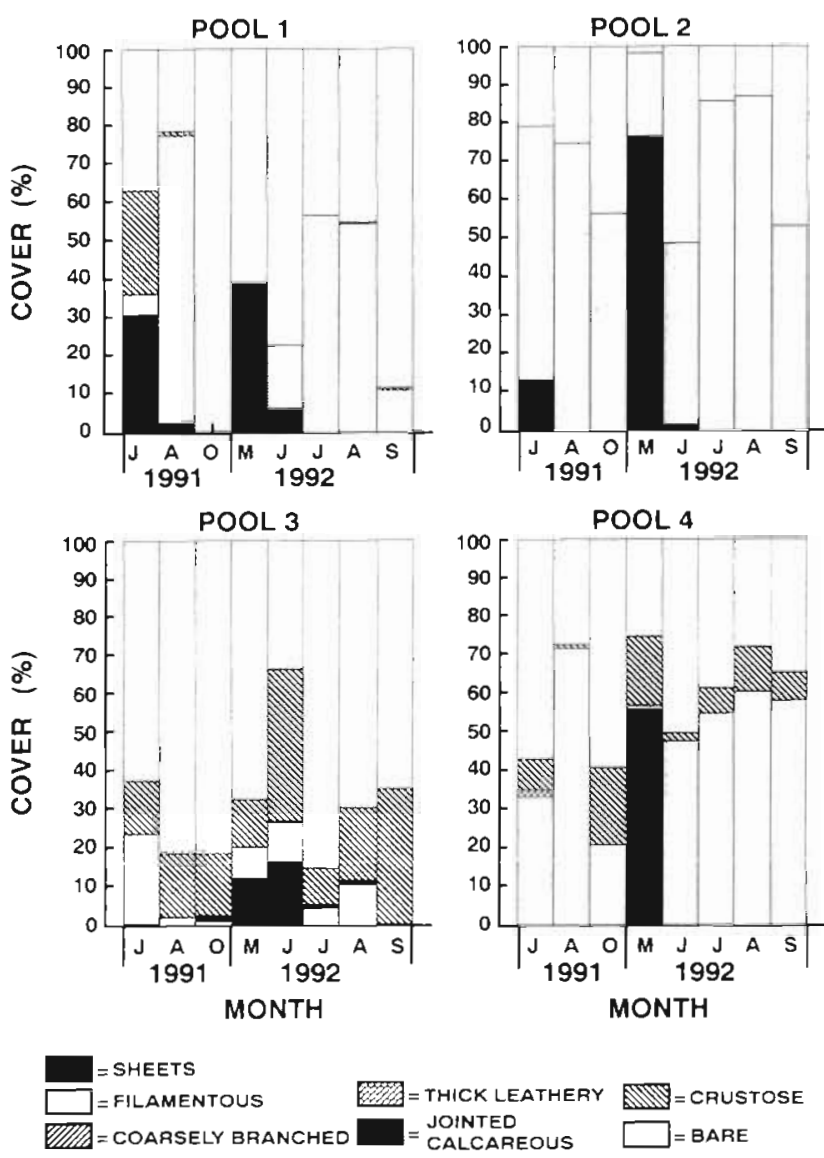

Fig. 3. Mean percentage cover of 6 functional forms of macroalgae and of bare substratum in 4 tidepools in the high intertidal zone at Cranberry Cove, Nova Scotia, sampled in June, August and October 1991, and at monthly intervals between May and September $1992(\mathrm{n}=5)$
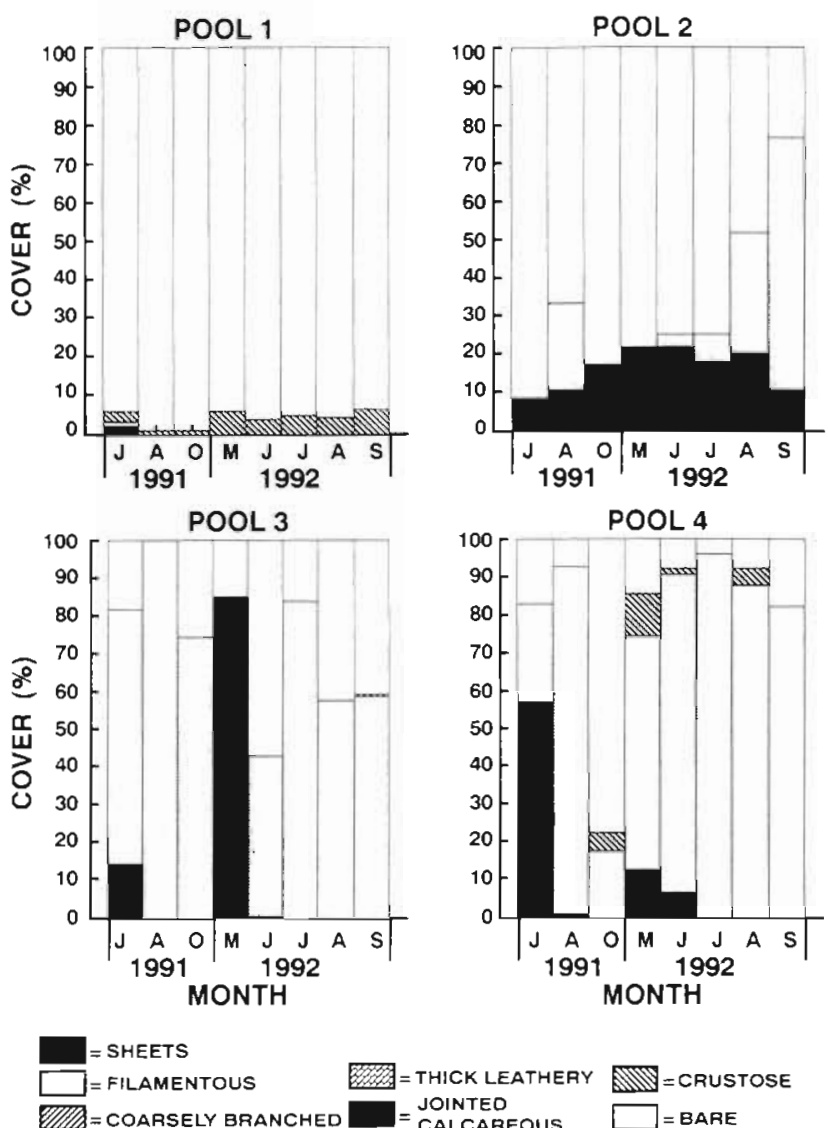

THICK LEATHERY JOINTEO
CALCAREOUS

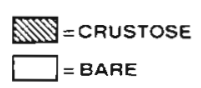

Fig. 4. Mean percentage cover of 6 functional forms of macroalgae and of bare substratum in 4 tidepools in the splash zone at Cranberry Cove, Nova Scotia, sampled in June, August and October 1991, and at monthly intervals between May and September $1992(n=5)$

\section{Spatial patterns of abundance}

Percentage cover of some of the functional form groups of macroalgae, especially the tougher in texture, varied significantly among intertidal zones on some sampling dates (Table 4). For example, percentage cover of thick leathery forms was larger in mid pools than in high and splash pools in June, August and October 1991 and May 1992, and it was larger in mid than in high pools (but not splash pools) in June 1992 (SNK tests, $\mathrm{p}<0.05$ ). Percentage cover of crustose forms was larger in the mid pools than in the splash pools in June and August 1991 (SNK tests, $p<0.05$ ). In contrast, percentage cover of sheets, filamentous, coarsely branched and jointed calcareous forms did not vary significantly among intertidal zones. Percentage cover of bare substratum was smaller in the mid pools than in the high and splash pools in June and October 1991, and in June, and September 1992 (SNK tests, $p<0.05$ ). 

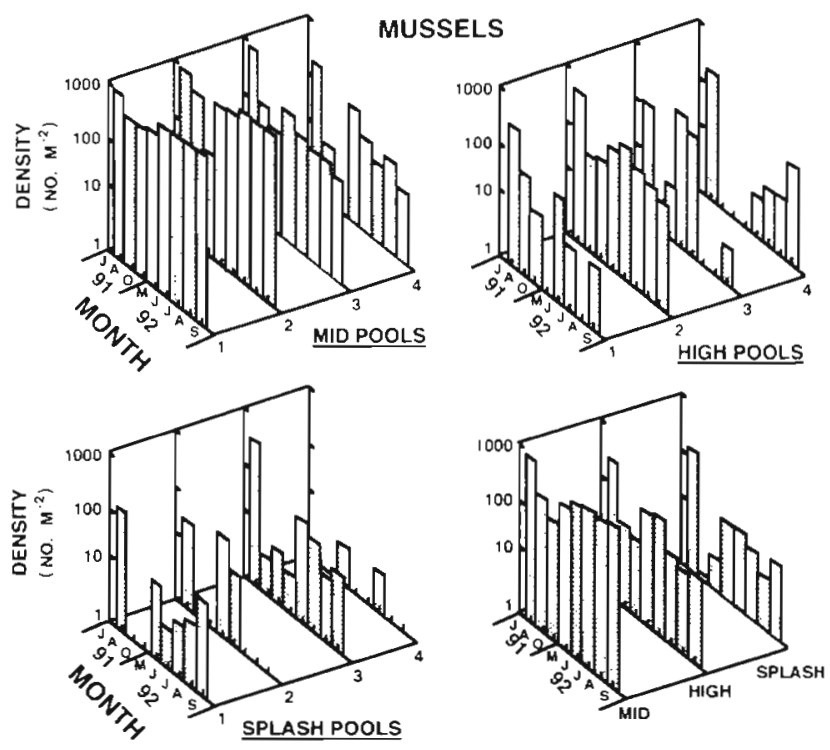

Fig. 5. Mytilus edulis and $M$. trossulus. Density of mussels in tidepools in 3 intertidal zones (mid, high and splash) at Cranberry Cove, Nova Scotia, sampled in June, August and October 1991, and at monthly intervals between May and September 1992. The first 3 panels show mean density in each tidepool, in each zone ( $n=5)$. The bottom right panel shows mean density in each intertidal zone (4 tidepools)
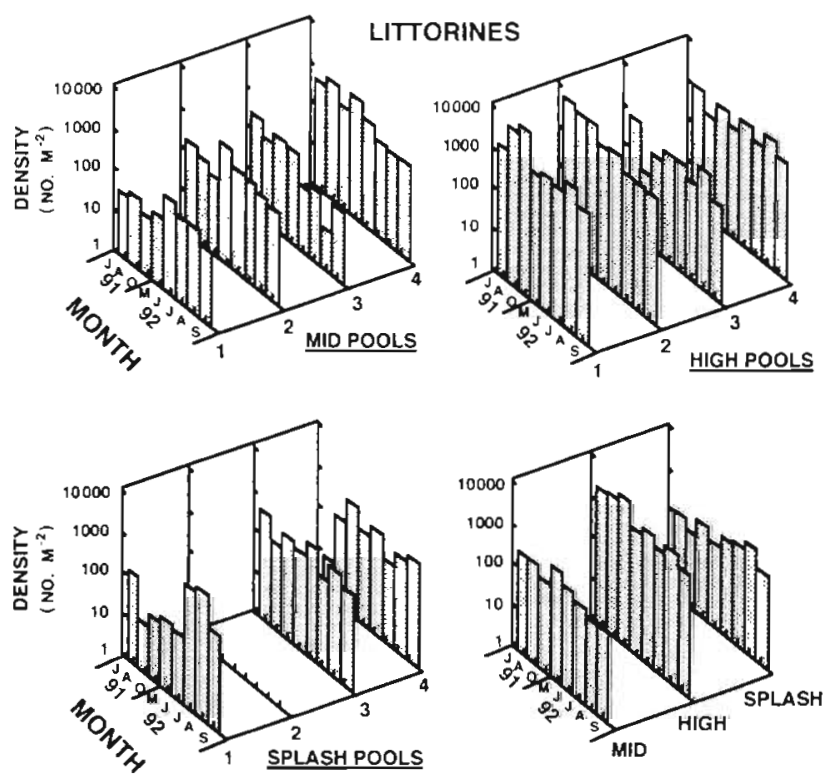

Fig. 6. Littorina littorea, L. obtusa and L. rudis. Density of littorinid snails in tidepools in 3 intertidal zones (mid, high and splash) at Cranberry Cove, Nova Scotia, sampled in June, August and October 1991, and at monthly intervals between May and September 1992. The first 3 panels show mean density in each tidepool in each zone $(n=5)$. The bottom right panel shows mean density in each intertidal zone (4 tidepools)
Percentage cover of most macroalgal functional groups varied significantly among pools within intertidal zones on most sampling dates (Table 4). Percentage cover of sheets varied significantly among splash pools on all sampling dates, among high pools in May 1992, and among mid pools from June to October 1991 and from May to July 1992. Percentage cover of filamentous forms varied significantly among pools in all zones on all sampling dates, except in June 1992 when it did not vary significantly among high pools. Percentage cover of coarsely branched forms varied significantly among mid pools in June 1991 (although the overall pool effect was not significant) and in August 1992. Percentage cover of thick leathery forms varied significantly among mid pools on all sampling dates (although the overall pool effect was not significant from June 1991 to May 1992). Percentage cover of jointed calcareous algae varied significantly among mid pools from August 1991 to September 1992 (although the overall pool effect was not significant in May 1992). Percentage cover of crustose forms varied significantly among high pools in June and October 1991 and in June, August and September 1992, and among mid pools in June 1991 and in July and August 1992. The amount of bare substratum varied significantly among splash pools in August and October 1991 and from May to September 1992, among high pools from June to October 1991, in May 1992 and
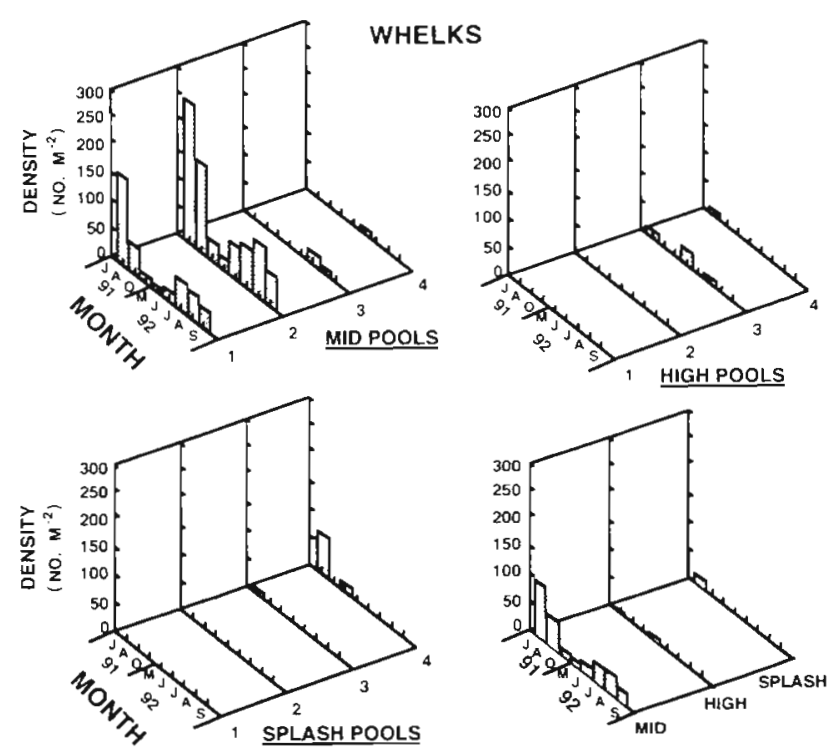

Fig. 7 Nucella lapillus. Density of whelks in tidepools in 3 intertidal zones (mid, high and splash) at Cranberry Cove, Nova Scotia, sampled in June, August and October 1991, and at monthly intervals between May and September 1992. The first 3 panels show mean density in each tidepool, in each zone $(n=5)$. The bottom right panel shows mean density in each intertidal zone ( 4 tidepools) 


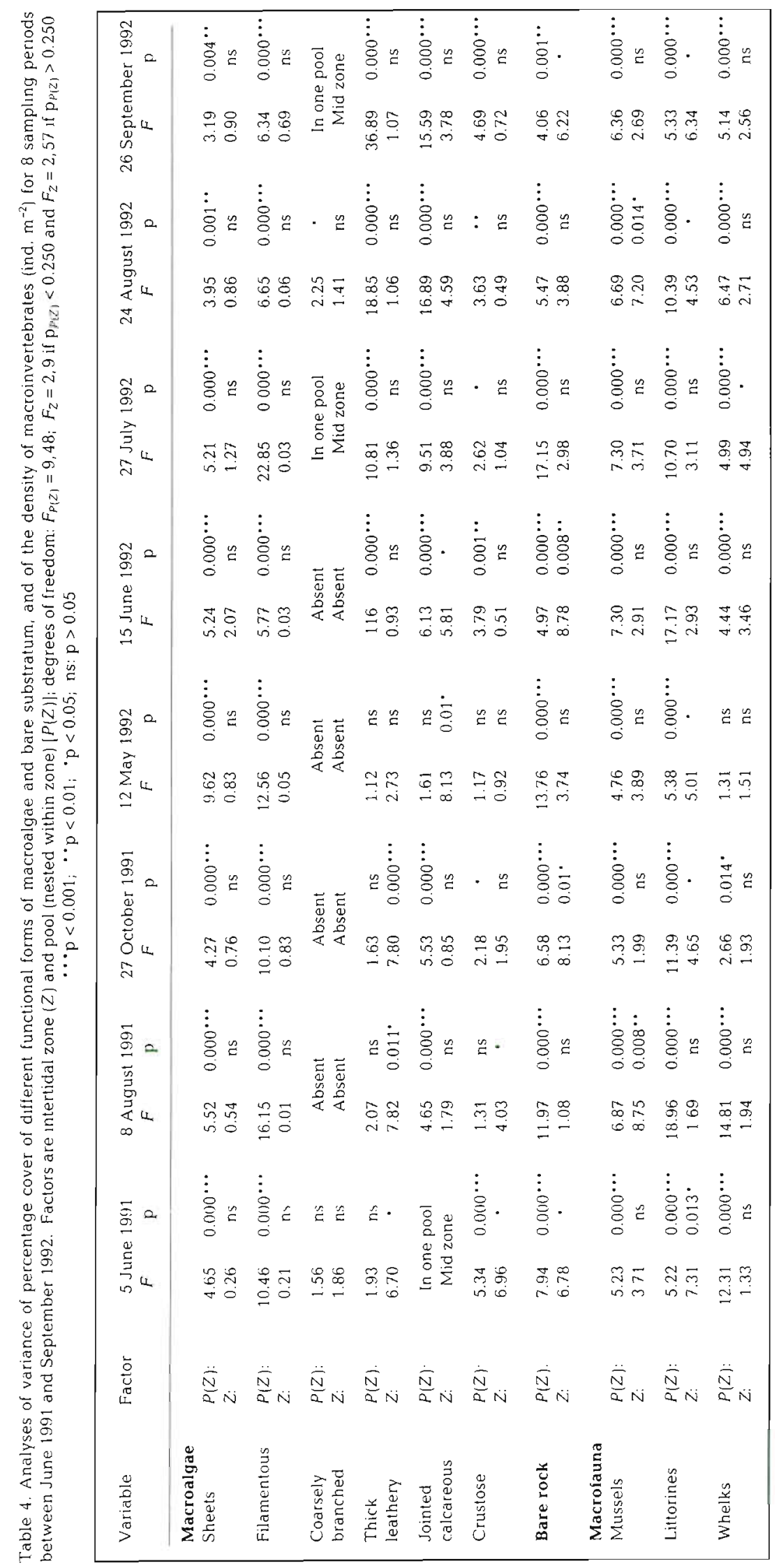

from July to September 1992, and among mid pools in June 1991.

In summary, only the thick leathery and crustose macroalgal groups varied in percentage cover among intertidal zones. However, high variability among pools within intertidal zones may mask differences among zones in the abundance of most macroalgal forms.

As with the macroalgae, the density of the 3 major macrofaunal groups varied among intertidal zones on only a few sampling dates (Table 4). Mussels were significantly more abundant in mid pools than in high and splash pools in August 1991 and 1992 (SNK tests, $p<0.05$ ). The few mussels which occurred in high and splash pools were found mostly in cracks and crevices. Littorines were significantly more abundant in high pools than in mid and splash pools in June and October 1991 and in September 1992 (SNK tests, p < 0.05). Littorines also were more abundant in high pools than in splash pools in May 1992, and in high pools than in mid pools in August 1992 (SNK tests, $p<0.05$ ). At the species level, only Littorina obtusata was more abundant in mid than high and splash pools in May $1992\left(F_{2,9}=5.64\right.$, $\mathrm{p}<0.05$, SNK test, $\mathrm{p}<0.05)$. Whelks were significantly more abundant in mid pools than in high and splash pools in July 1992 (SNK tests, p < 0.05 ).

The density of the major macrofaunal groups also varied among pools within zones on most sampling dates (Table 4). Mussels varied significantiy among mid pools on all sampling dates, among high pools in August and October 1991 and from May to August 1992, and among splash pools in June 1991, May, July and September 1992. Littorines varied significantly among mid pools in June and August 1991, and in May and June 1992, among high pools in August and October 1991 and from May to September 1992, and among splash pools from June to October 1991 and from June to September 
1992. Whelks varied significantly among mid pools from June to October 1991 and from June to September 1992, and among splash pools in June 1991.

The few significant differences in the density of macrofauna among intertidal zones that we observed were not consistent for any group. As for the macroalgae, high variability among pools within zones appears to mask differences among zones.

\section{Determinants of macroalgal abundance}

Percentage cover of macroalgae did not vary consistently with grazer and mussel abundance, the nutrient regime and the physical characteristics of the pools for the different functional groups (Table 5). The number of significant regressions was smallest for sheets and larger for the thick leathery and crustose macroalgal

Table 5. Significant backwards elimination multiple regressions for percentage cover of 6 functional groups of macroalgae against the biological and physical characteristics of tidepools for the entire sampling period and 8 separate sampling times between June 1991 and September 1992. Independent variables: $\mathrm{S}=$ snail abundance; $\mathrm{M}=$ mussel abundance; $\mathrm{H}=$ height above chart datum; $\mathrm{A}=$ surface area; $\mathrm{V}=$ volume $\mathrm{F}=$ flushing rate $\mathrm{PO}=$ phosphate concentration; $\mathrm{NO}=$ nitrate + nitrite concentration; $\mathrm{NH}=$ ammonium concentration; $\mathrm{N}: \mathrm{P}=$ dissolved nitrogen to phosphorus ratio. Within each multiple regression, independent variables with significant partial F-values are shown in bold print

\begin{tabular}{|c|c|c|c|c|c|c|}
\hline $\begin{array}{l}\text { Dependent } \\
\text { variable }\end{array}$ & Date & $\mathrm{N}$ & Model & $\mathrm{R}^{2}$ & $F$ & $\mathrm{p}$ \\
\hline Sheets & 5 Jun 91 & 12 & $\begin{aligned}= & -77.47+0.011(\mathrm{~S})+0.026(\mathrm{M})+7.890(\mathrm{H})-6.605(\mathrm{~A})+15.74(\mathrm{~V}) \\
& -0.438(\mathrm{~F})+315(\mathrm{PO})-82.08(\mathrm{NO})-625(\mathrm{NH})+33.47(\mathrm{~N}: \mathrm{P})\end{aligned}$ & 1.000 & 666 & $\cdot$ \\
\hline \multirow[t]{3}{*}{ Filamentous } & All dates & 96 & $=-10.34+11.51(\mathrm{H})+0.369(\mathrm{~F})$ & 0.120 & 6.24 & $0.003^{*}$ \\
\hline & 5 Jun 91 & 12 & $\begin{aligned}= & 452-0.017(\mathrm{~S})+4.361(\mathrm{~A})-28.01(\mathrm{~V})+0.752(\mathbf{F})-884(\mathrm{PO}) \\
& +140(\mathrm{NO})+1242(\mathrm{NH})-101(\mathrm{~N}: \mathbf{P})\end{aligned}$ & 0.983 & 21.69 & $0.014^{*}$ \\
\hline & 8 Aug 91 & 12 & $=-36.65+0.017(\mathrm{~S})-0.210(\mathrm{M})+1.304(\mathrm{~F})+103(\mathrm{PO})-5.230(\mathrm{NO})$ & 0.872 & 8.14 & $0.012^{\circ}$ \\
\hline \multirow{3}{*}{$\begin{array}{l}\text { Coarsely } \\
\text { branched }\end{array}$} & All dates & 96 & $=-0.348+0.004(\mathrm{M})$ & 0.350 & 50.71 & $0.000 \cdots$ \\
\hline & 5 Jun 91 & 12 & $=-1.747+0.051(\mathrm{~A})+0.013(\mathrm{~F})+0.456(\mathrm{NO})+13.20(\mathrm{NH})$ & 0.921 & 20.77 & $0.001 \cdots$ \\
\hline & 24 Aug 92 & 12 & $=-0.491+0.009(\mathrm{M})$ & 0.746 & 29.43 & $0.000^{\cdots}$ \\
\hline \multirow{9}{*}{$\begin{array}{l}\text { Thick } \\
\text { leathery }\end{array}$} & All dates & 96 & $=20.77-6.154(\mathrm{H})-1.685(\mathrm{~A})+4.204(\mathrm{~V})+0.271(\mathrm{~F})$ & 0.739 & 64.48 & $0.000^{\cdots} \cdots$ \\
\hline & 5 Jun 91 & 12 & $\begin{aligned}= & 40.60-0.004(\mathrm{~S})-0.009(\mathrm{M})-11.23(\mathrm{H})+0.313(\mathrm{~F})+8.558(\mathrm{NO}) \\
& -6.168(\mathrm{~N}: \mathrm{P})\end{aligned}$ & 0.949 & 15.53 & $0.004 \cdots$ \\
\hline & 8 Aug 91 & 12 & $\begin{aligned}= & 32.57+0.023(\mathrm{M})-0.023(\mathrm{H})-1.731(\mathrm{~A})+3.796(\mathrm{~V})-0.058(\mathrm{~F}) \\
& +13.64(\mathrm{PO})-1.163(\mathrm{NO})-123(\mathrm{NH})+0.655(\mathrm{~N}: \mathrm{P})\end{aligned}$ & 1.000 & 910 & $0.001 *$ \\
\hline & 27 Oct 91 & 12 & $\begin{aligned}= & 37.07+0.074(\mathrm{M})-4.507(\mathrm{~A})+9.688(\mathrm{~V})+0.314(\mathrm{~F})-8.518(\mathrm{NO}) \\
& -125(\mathrm{NH})-2.078(\mathrm{~N}: \mathrm{P})\end{aligned}$ & 0.456 & 11.07 & $\cdot$ \\
\hline & 12 May 92 & 12 & $\begin{aligned}= & 33.64+0.009(\mathrm{~S})+0.055(\mathrm{M})-5.642(\mathrm{H})-1.384(\mathrm{~A})-69.99(\mathrm{PO}) \\
& +12.48(\mathrm{NO})-2885(\mathrm{NH})-0.860(\mathrm{~N}: \mathrm{P})\end{aligned}$ & 0.987 & 29.35 & $0.009 \cdot$ \\
\hline & 15 Jun 92 & 12 & $\begin{aligned}= & 149-18.79(\mathrm{H})-7.644(\mathrm{~A})+17.19(\mathrm{~V})+0.699(\mathrm{~F})-125(\mathrm{PO}) \\
& +37.87(\mathrm{NO})+13.62(\mathrm{NH})-15.53(\mathrm{~N}: \mathrm{P})\end{aligned}$ & 0.989 & 32.93 & $0.008 *$ \\
\hline & 24 Jul 92 & 12 & $=-9.105+0.333(\mathbf{F})$ & 0.413 & 7.03 & $\cdot$ \\
\hline & 24 Aug 92 & 12 & $=-15.38+0.010(\mathrm{~S})-2.892(\mathbf{A})+9.196(\mathrm{~V})+0.631(\mathrm{~F})$ & 0.784 & 6.36 & $\cdot$ \\
\hline & $26 \operatorname{Sep} 92$ & 12 & $=-2.829-1.554(\mathrm{~A})+4.431(\mathrm{~V})+0.356(\mathrm{~F})$ & 0.712 & 6.59 & • \\
\hline \multirow{4}{*}{$\begin{array}{l}\text { Jointed } \\
\text { calcareous }\end{array}$} & All dates & 96 & $=-1.566-0.266(\mathrm{~A})+1.046(\mathrm{~V})+0.087(\mathrm{~F})$ & 0.253 & 10.39 & $0.000^{\cdots}$ \\
\hline & 8 Aug 91 & 12 & $=-0.297+0.011(\mathrm{M})$ & 0.711 & 24.57 & $0.001 \cdots$ \\
\hline & 12 May 92 & 12 & $=0.242+0.013(\mathrm{M})-0.740(\mathrm{~V})$ & 0.669 & 9.10 & $0.007 *$ \\
\hline & 15 Jun 92 & 12 & $\begin{aligned}= & 78.90-0.003(\mathrm{~S})-0.012(\mathrm{M})-8.504(\mathrm{H})-3.107(\mathrm{~A})+7.153(\mathrm{~V}) \\
& +0.390(\mathbf{F})-87.61(\mathrm{PO})+27.55(\mathrm{NO})+14.92(\mathrm{NH})-11.20(\mathrm{~N}: \mathrm{P})\end{aligned}$ & 1.000 & 1744 & $\cdot$ \\
\hline \multirow[t]{8}{*}{ Crustose } & All dates & 96 & $=0.306+0.016(\mathrm{M})+2.673(\mathrm{~V})$ & 0.323 & 22.18 & $0.000^{\cdots \cdots}$ \\
\hline & 5 Jun 91 & 12 & $\begin{aligned}= & 42.77+0.021(\mathrm{M})-18.88(\mathrm{H})-4.541(\mathrm{~A})+16.21(\mathrm{~V})+160(\mathrm{PO}) \\
& -736(\mathrm{NH})\end{aligned}$ & 0.896 & 7.19 & • \\
\hline & 8 Aug 91 & 12 & $=1.493-0.001(\mathrm{~S})+0.040(\mathrm{M})+0.829(\mathrm{~A})-0.170(\mathrm{~F})$ & 0.773 & 5.96 & $\cdot$ \\
\hline & 27 Oct 91 & 12 & $=1.646-0.003(\mathrm{~S})-4.392(\mathrm{~V})+66.17(\mathrm{PO})-8.703(\mathrm{NO})$ & 0.767 & 5.76 & $\cdot$ \\
\hline & 15 Jun 92 & 12 & $=-6.154+0.005(\mathrm{M})+6.235(\mathrm{~V})+4.990(\mathrm{NH})$ & 0.916 & 29.18 & $0.000^{*}$ \\
\hline & 24 Jul 92 & 12 & $=0.040+0.009(\mathrm{M})+1.218(\mathrm{~V})$ & 0.676 & 9.40 & *. \\
\hline & 24 Aug 92 & 12 & $=1.962+2.553(\mathbf{V})$ & 0.423 & 7.33 & $\cdot$ \\
\hline & $26 \operatorname{Sep} 92$ & 12 & $=2.673+0.005(\mathrm{M})+4.518(\mathrm{~V})-0.120(\mathrm{~F})$ & 0.893 & 22.25 & $0.000^{\cdots}$ \\
\hline
\end{tabular}


forms. Sheets varied significantly with all the factors in the model, but only in June 1991. Filamentous forms varied significantly with the physical characteristics of the pool in 3 regression models, with snail abundance and nutrient concentrations in 2 models, and with mussel abundance in 1 model. Coarsely branched forms varied significantly with mussel abundance in 2 regression models and with nutrient concentration and the physical characteristics of the tidepools in 1 model. Thick leathery forms varied significantly with physical characteristics of the pools in 8 regression models, with nutrient concentrations in 4 models and with snails and mussels in 1 model. Jointed calcareous macroalgae varied significantly with mussel abundance in 3 regression models, with the physical characteristics of the pools in 2 models and with snail abundance and nutrient concentration in 1 model. Crustose forms varied significantly with the physical characteristics of the pool in 7 regression models, with mussel abundance and nutrient concentration in 3 models and with snail abundance in 1 model.

For most macroalgal functional groups, the regression models that were obtained for each individual sampling date explained a larger proportion of the variance than the models for the entire sampling period. Overall, the number of significant relationships between macroalgal abundance and the physical and biological characteristics of the pools was larger for the tougher thick leathery and crustose groups than for sheets and filamentous algae.

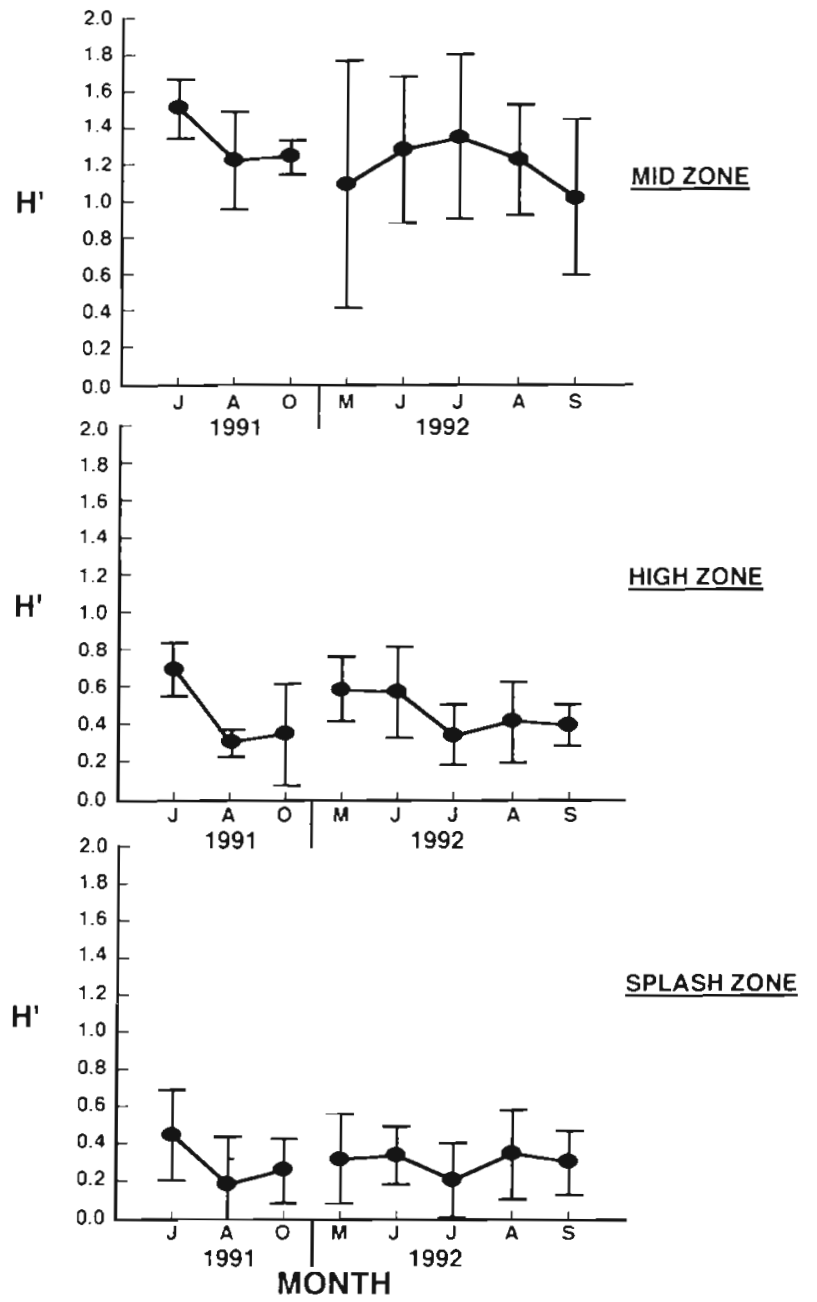

Fig. 8. Shannon Diversity Indices $( \pm S D, n=4)$ of the macroalgal communities in tidepools in 3 intertidal zones (mid, high and splash), at Cranberry Cove, Nova Scotia, sampled in June, August and October 1991, and at monthly intervals between May and September 1992

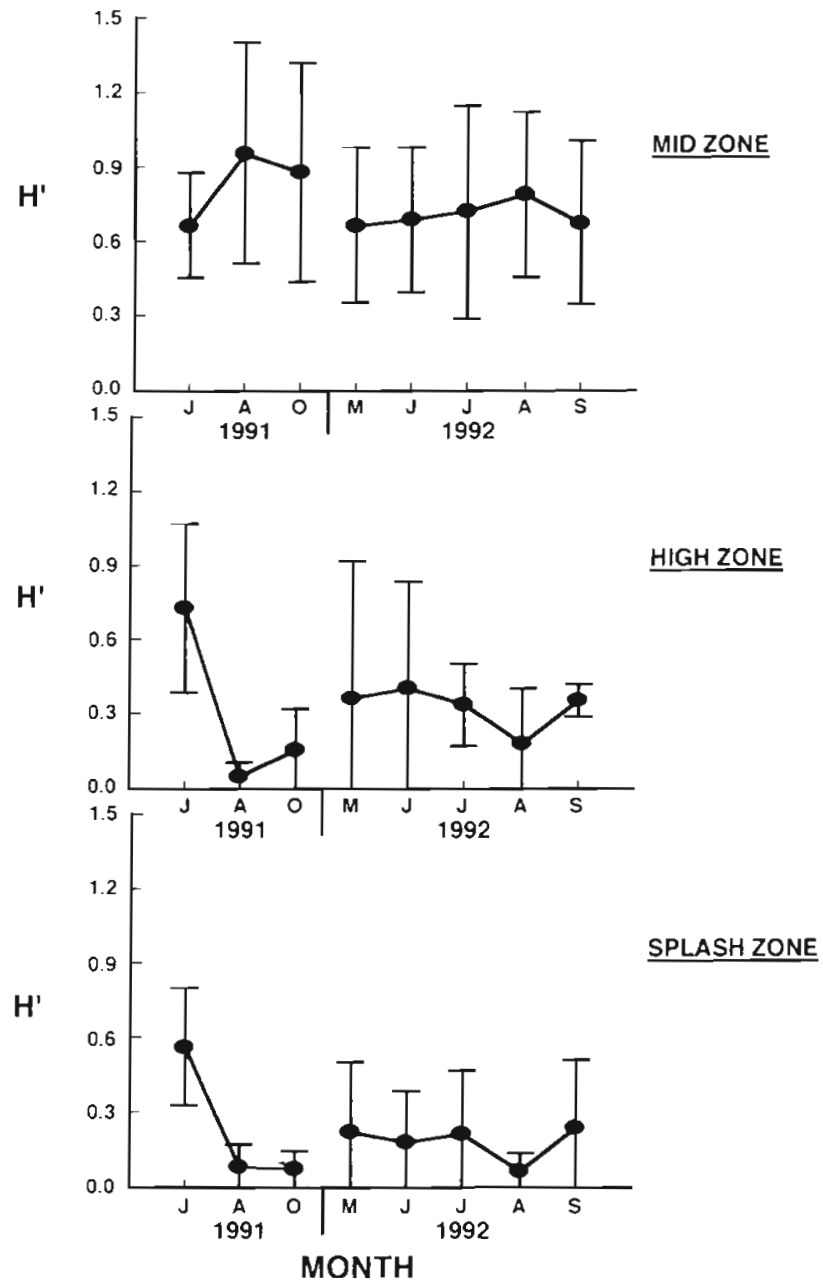

Fig. 9. Shannon Diversity Indices $( \pm S D, n=4)$ of the macroinvertebrate communities in tidepools in 3 intertidal zones (mid, high and splash), at Cranberry Cove, Nova Scotia, sampled in June, August and October 1991, and at monthly intervals between May and September 1992 


\section{Patterns of species diversity and community similarity}

The Shannon Diversity Index $\left(H^{\prime}\right)$ calculated for the macroalgal assemblages of the pools was largest in mid pools and smallest in splash pools $\left(F_{2,72}=107.6\right.$, $\mathrm{p}<0.001$; SNK test, $\mathrm{p}<0.05)_{i} H^{\prime}$ calculated for the macrofaunal assemblages was larger in mid pools than high and splash pools $\left(F_{2,72}=30.99, \mathrm{p}<0.001\right.$; SNK test, p < 0.05) (Figs. $8 \& 9$ ). $H^{\prime}$ for both the macroalgal and macrofaunal assemblages did not vary significantly over the entire sampling period $\left(F_{7,72}=1.69\right.$ and 1.32 , respectively, $\left.\mathrm{p}>0.05\right)$ and there was no significant interaction between time and zone effects $\left(F_{14,72}=0.477,1.23\right.$, respectively, $\left.\mathrm{p}>0.05\right)$.

Cluster analyses based on the macroalgal assemblages of tidepools showed that the mid pools clus-
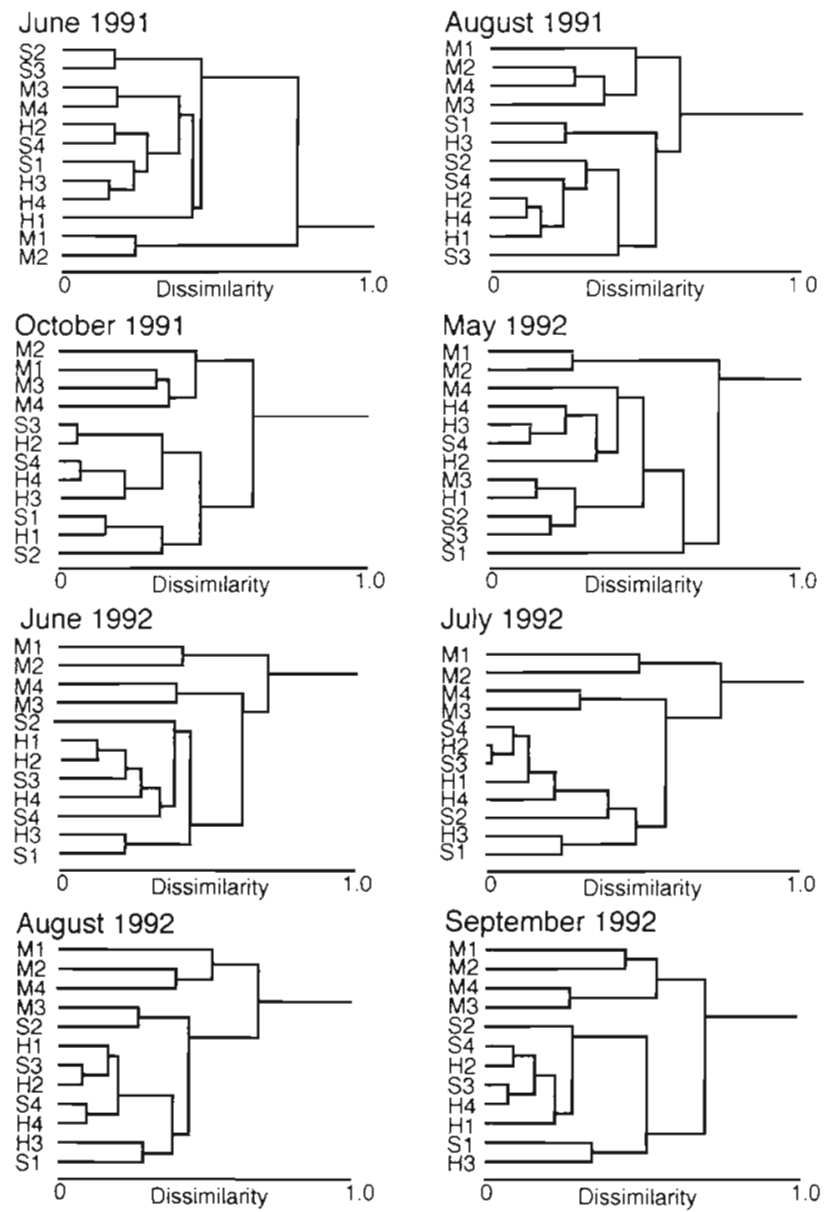

Fig. 10. Cluster analyses of the macroalgal communities in 4 tidepools $(1,2,3,4)$ in each of 3 intertidal zones (M: mid, $\mathrm{H}$ : high, S: splash), at Cranberry Cove, Nova Scotia, sampled in June, August and October 1991, and at monthly intervals between May and September 1992
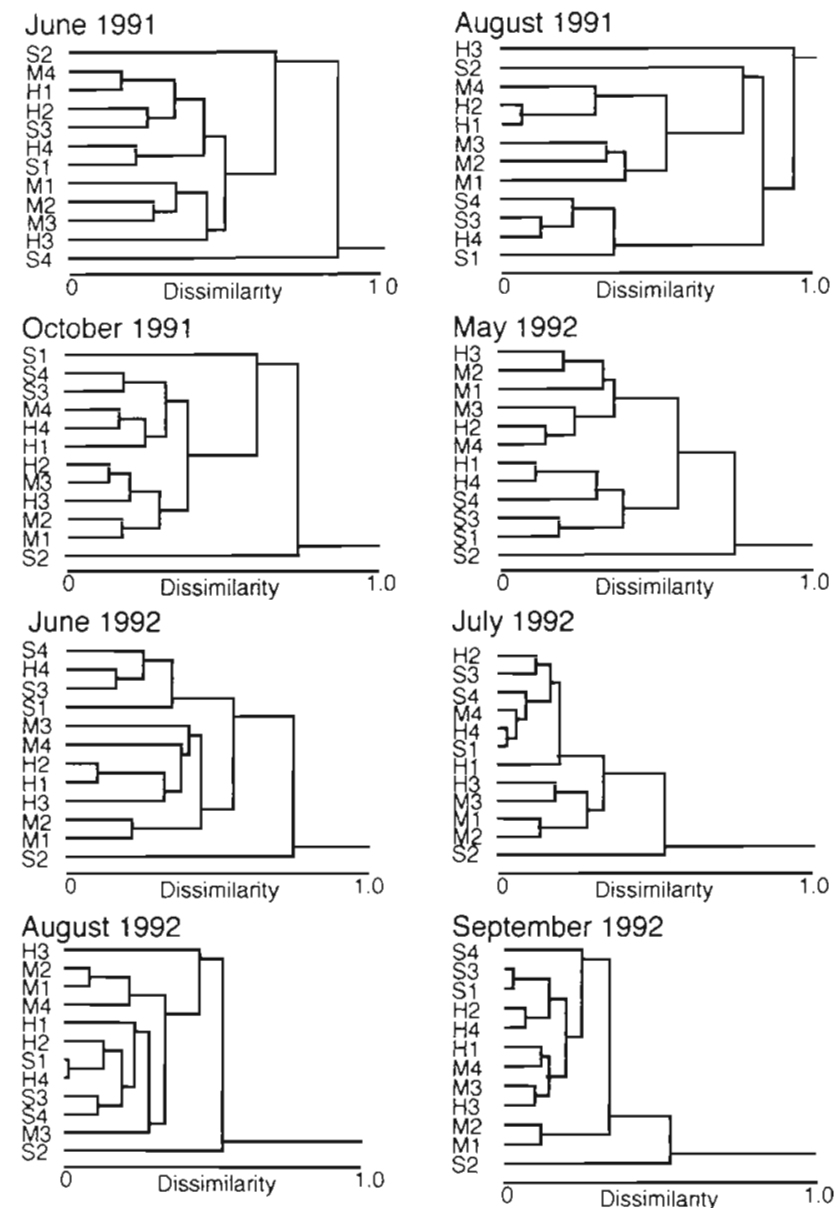

Fig. 11 Cluster analyses of the macroinvertebrate communities in 4 tidepools $(1,2,3,4)$ in each of 3 intertidal zones (M: mid, H: high, S: splash), at Cranberry Cove, Nova Scotia, sampled in June, August and October 1991, and at monthly intervals between May and September 1992

tered in pairs in June 1991, but by August 1991 all 4 mid pools belonged to the same cluster, which was maintained in October 1991 (Fig. 10). Similarly, in 1992, the mid pools were in separate clusters in May, but grouped more closely from June through September. The only other cluster of pools that was evident in August 1991 and from. July to September 1992 was a high pool (Pool 3) and a splash pool (Pool 1); the remaining high and splash pools usually belonged to the same cluster. Cluster analysis based on the macrofaunal assemblages gave less clear results, although mid pools usually clustered closer to high pools than splash pools (Fig. 11). Certain high and splash pools were frequently dissimilar to the other pools. For example, 1 splash pool (Pool 2) was highly dissimilar to any other pool on any sampling date. 


\section{DISCUSSION}

\section{Temporal and spatial patterns of abundance}

Seasonal patterns of abundance of sheets and some filamentous and coarsely branched forms of macroalgae in our study contrasted with the patterns observed in 2 previous studies of tidepools in Maine (Femino \& Mathieson 1980) and Rhode Island (Wolfe \& Harlin 1988a), USA. We found that sheets, such as Enteromorpha intestinalis, Petalonia fascia, Scytosiphon lomentaria and Ulva lactuca, were present mostly in early summer, whereas Femino \& Mathieson (1980) and Wolfe \& Harlin (1988a) recorded the occurrence of $U$. lactuca and $S$. lomentaria throughout the year. We found some filamentous forms, such as Cladophora sp. and Spongomorpha sp., in the pools throughout the year, whereas Femino \& Mathieson (1980) recorded these forms only in late spring and early summer. In contrast, we found other filamentous forms, such as Ceramium rubrum and Chaetomorpha melagonium. mainly in late spring and summer, whereas Femino \& Mathieson (1980) and Wolfe \& Harlin (1988a) found that they were present throughout most of the year. We found coarsely branched forms, such as Chordaria flagelliformis, only in late summer, whereas Femino \& Mathieson (1980) found that they were present from early spring to late fall. Some of these regional differences in macroalgal seasonality may be due to harsher conditions in the spring in Nova Scotia compared to the northeastern USA. The pools in our study freeze in the winter which may preclude the occurrence, at least in a macroscopic form, of sheets, some filamentous algae and the coarsely branched algae during this period. Differences in physical characteristics, such as intertidal height or degree of exposure, between the pools in our study and those in the 2 previous studies also may account for some of the inconsistencies. Percentage cover of thick leathery and crustose forms did not vary seasonally in our study and in those by Femino \& Mathieson (1980) and Wolfe \& Harlin (1988a).

Intertidal zonation in tidepools was observed for some macroalgal genera and functional form groups, but not for others, and these observations were not always consistent with previous studies. Percentage cover of thick leathery forms, such as Fucus vesiculosus, and crustose macroalgal forms, such as Phymatolithon sp., was greater in mid pools than in high and splash pools. Similar zonation patterns were observed in studies by Fraser (1936) on the Isle of Man, UK, Green (1971) in British Columbia, Canada, Daniel \& Boyden (1975) at St. Bride's Haven, UK, and Femino \& Mathieson (1980) in Maine. In contrast, Wolfe \& Harlin (1988a) found thick leathery (Fucus vesiculosus and
Ascophyllum nodosum) and crustose forms in pools throughout the intertidal gradient, but the pools in their study were lower than the ones we used. In our study, there was no clear zonation of sheets, or coarsely branched macroalgal forms, and among the filamentous forms, only Cladophora sp. showed significant differences in abundance among zones. In contrast, other studies have found that some sheets and filamentous forms, such as the green algal genus Spongomorpha and the brown algal genus Scytosiphon, were more abundant in lower pools, whereas others, such as the green algal genera Chaetomorpha, Cladophora and Enteromorpha, were more abundant in higher pools (Fraser 1936, Femino \& Mathieson 1980, Sze 1982, Wolfe \& Harlin 1988a).

Steneck \& Dethier (in press) examined the distribution of macroalgal functional forms, similar to those in our study, in relation to a gradient of decreasing productivity potential with increasing intertidal height on a rocky shore in Maine. Productivity potential was determined by extrinsic factors (e.g. light, nutrient levels, desiccation and freezing) that set the maximum limit of net primary productivity for that environment. Their model suggested that with decreasing productivity potential, leathery and crustose macrophytes should be replaced by macrophytes with lower canopy heights, such as filamentous groups, and eventually crustose algae as the dominant forms. Although the distribution of the leathery and crustose forms in our study generally agrees with that predicted by their model, the lack of zonation of the sheets and filamentous algae does not.

Littler \& Littler $(1980,1984)$ have characterized thick leathery and crustose macroalgai forms as late successional forms that are poor colonizers. They have more complex structures, higher maintenance costs, and lower productivity than the other groups. Sheets, filamentous and coarsely branched forms are more opportunistic and better colonizers. They allocate most of their energy to reproduction and have higher productivity. The greater abundance of thick leathery and crustose forms in mid pools, compared to those higher on the shore, may be attributable to the more benign and predictable environment in mid pools due to regular inundation by the tides (for review see Metaxas \& Scheibling 1993). In high and splash pools, larger fluctuations in temperature and salinity due to evaporation and freezing create a harsher environment which many of these forms may not tolerate. According to the classification of Littler \& Littler (1980, 1984), the more opportunistic, highly productive forms, such as sheets and filamentous algae, can quickly colonize and establish populations when space becomes available. In our study, gaps which occurred in mid pools in the spring, and in high and splash pools throughout the year, were readily colonized by these forms 
Percentage cover of all macroalgal functional form groups varied markedly among pools within each zone. Some groups, such as some filamentous and coarsely branched forms, appeared sporadically in mid pools in the spring and summer, respectively. Other groups, such as sheets, filamentous, thick leathery, jointed calcareous, and crustose forms, were present in large abundances in some pools but were completely absent from others. The amount of bare substratum was most variable among high and splash pools in late summer and fall, a period during which heavy wave action due to storms dislodged most of the macroalgal canopy (pers. obs.). The large horizontal variability in percent macroalgal cover that we observed among pools with similar periods of tidal isolation may reflect, in part, the variability of recruitment. Furthermore, many of the factors or processes influencing recruitment and survival of macroalgae may vary greatly among individual tidepools and cannot be generalized to intertidal zones.

There was less variability among intertidal zones in macrofaunal abundance than in macroalgal cover. Abundance of mussels, littorines and whelks peaked in summer due to recruitment (Minchinton 1989, Pedersen 1991). Mussels were much more abundant in mid pools than in high and splash pools. We did not record mussels $>2 \mathrm{~cm}$ in higher pools, suggesting that their survivorship there was low, presumably due to the harsher conditions. Clarke \& Griffiths (1990) suggested that mussels living in tidepools have a larger metabolic cost than those on the emergent substratum because mussels can shut down their metabolism completely when emerged. Whelks were rare in high and splash pools indicating low recruitment, immigration and/or survival there. Littorinid snails were found in pools of all zones (with the exception of 1 pool in the splash zone where they were never found) but were most abundant in high pools. The zonation of macrofauna that we observed is consistent with previous studies of tidepools on rocky shores (Fraser 1936, Ganning 1971. Daniel \& Boyden 1975, Goss-Custard et al. 1979, Femino \& Mathieson 1980). As for the macroalgae, large variability among pools within zones was detected for each of the 3 major groups of macrofauna. Mussel abundance varied significantly among high and splash pools. Littorinid and whelk abundance varied among pools in all zones, mostly in summer. This variability may reflect differential recruitment among pools or differential mortality due to environmental conditions which are specific to individual pools.

\section{Determinants of macroalgal abundance}

Multiple linear regressions showed that the relationship between macroalgal percentage cover and snail and mussel abundance, the nutrient regime, and the physical characteristics of tidepools varied among macroalgal functional form groups. For all groups, a smaller proportion of the variance in percentage cover was explained when the regressions were done for the entire sampling period than for each sampling date, suggesting that the factors affecting cover may change throughout the year. The number of significant regressions was smaller for the more opportunistic, highly productive forms, such as sheets and filamentous forms, than for the late successional, less productive, thick leathery and crustose forms. This is consistent with the view that more opportunistic forms should be capable of rapid growth under a range of environmental conditions, whereas the later successional forms should tend to be physiologically adapted to a more predictable environment (Littler 1980, Littler \& Littler 1980, 1984).

None of the macroalgal forms showed a strong, consistent relationship with the dominant grazers in the pools. This may be because the more opportunistic forms can escape losses due to grazing by rapid growth, and later successional forms have reduced palatability (Littler \& Littler 1980). However, these observations are inconsistent with previous experimental studies which have manipulated grazers in tidepools in the northwest Atlantic. Lubchenco (1982) showed that the cover of some sheets, filamentous, and thick leathery macroalgae increased when grazer density was decreased in mid pools in a protected and a semi-exposed site, in Maine and Massachusetts, USA, respectively. Chapman (1990) working in high pools at an exposed site ca $5 \mathrm{~km}$ east of ours showed that grazer removals resulted in an increase in sheets but a decrease in thick leathery forms. Parker et al. (in press) working in high pools at our site, found a significant decrease in cover of most functional forms in the presence of littorinid grazers in early successional stage communities, but Parker \& Chapman (in press) detected no effects of littorinids on canopy macroalgal groups in established communities in high pools at Sandy Cove, Nova Scotia. The inconsistency of results among different studies support our suggestion that the importance of grazing may vary among tidepools, and it may not be easily generalizable across intertidal zones, sites or regions (e.g. northwest Atlantic).

All macroalgal functional forms showed a significant relationship with mussel abundance. This may be because they use them as a substrate (e.g. coarsely branched and some filamentous forms; pers. obs.) or compete with them for space. Although, to our knowledge, no studies have examined competitive processes in tidepools that involve mussels, competition among mussels and macroalgae has been demonstrated on emergent substrata of the rocky shores of the north- 
west Atlantic (e.g. Lubchenco \& Menge 1978, but see McCook \& Chapman 1991).

The percentage cover of all macroalgal forms tended to vary with the nutrient regime in summer and fall. periods of low ambient nutrient concentration. The cover of all macroalgal forms also varied significantly with some physical characteristic of the pools, thick leathery and crustose forms more so than sheets or filamentous macroalgae. This suggests that the physical setting of the pool may be of primary importance in determining macroalgal abundance. The physical environment is determined by a combination of factors such as intertidal height, topography, depth, volume and wave exposure that is unique to each pool (see Metaxas \& Scheibling 1993 for review).

\section{Patterns of species diversity and community similarity}

Macroalgal species diversity was greater in mid pools than in high and splash pools probably because fewer species can tolerate the harsher conditions in the higher pools. As previously mentioned, high and splash pools were dominated by opportunistic, macroalgal forms, whereas all functional forms were found in the mid pools. Macroalgal species diversity tended to be lowest in summer and fall, especially in mid pools, when intensive grazing by littorinids probably reduced the abundance of the newly recruited sheet, filamentous and coarsely branched forms. Macrofaunal species diversity also was greater in mid than in high and splash pools in summer and fall, periods of maximal fluctuations in the physical conditions of these higher pools (A. Metaxas unpubl. data). Previous studies also have shown a decrease in the number of algal and macroinvertebrate species in pools with increasing intertidal height (Femino \& Mathieson 1980, Huggett \& Griffiths 1986, Wolfe \& Harlin 1988b, Kooistra et al. 1989).

Because of the large variability among pools in macroalgal and macrofaunal abundance, pools did not cluster strongly with intertidal height. Opportunustic macroalgal forms appeared only in some mid pools in the spring resulting in low similarity until summer when most of these newly recruited algae had disappeared. A high pool (Pool 3) and a splash pool (Pool 1) formed a tight cluster in late summer in both years when both had lost all ephemeral macroalgal cover and were covered only with the prostrate form Hildenbrandia rubra or were completely bare. The remaining high and splash pools did not form distinct clusters, suggesting that differences in tidal input between these zones are not sufficiently pronounced to have a marked effect on the macroalgal communities. Similar- ity among tidal zones was even less pronounced for the macrofaunal communities. There was large variability among high and splash pools, with certain pools frequently being dissimilar to all others. In general, mid pools were more similar to high pools than splash pools, suggesting that macrofaunal communities probably are influenced to some degree by regular tidal input regardless of its frequency.

In summary, although significant variability among intertidal zones in percentage cover of macroalgae in tidepools was detected for some functional forms, large and consistent variability in percentage cover of all groups occurred among pools within zones. Therefore, horizontal spatial variability in macroalgal abundance appears to be as great as variability along the intertidal gradient. This suggests that differences in the physical characteristics of individual pools are as important as the period of tidal isolation of the pool in determining macroalgal community composition.

Acknowledgements. We thank Drs S. Walde and D. G. Webb for their comments on earlier drafts of this manuscript and Dr M. N. Dethier and 2 anonymous reviewers for their critical reviews. Pierre Clement at the Marine Chemistry Division of the Department of Fisheries and Oceans at the Bedford Institute of Oceanography (Dartmouth, Nova Scotia, Canada) analyzed the nitrate and phosphate samples. H.L.H. was supported by a Natural Sciences and Engineering Research Council of Canada (NSERC) Undergraduate Summer Research Award, and by a Sarah Lawson award for research in Botany from the Department of Biology, Dalhousie University. A.M. was supported by an 'Alexander S. Onassis' Public Benefit Foundation Postgraduate Scholarship (Athens Greece) and a scholarship from the Faculty of Graduate Studies, Dalhousie University. The research was funded by an NSERC Operating Grant to R.E.S.

\section{LITERATURE CITED}

Bennett, B. A., Griffiths, C. L. (1984). Factors affecting the distribution, abundance and diversity of rock-pool fishes on the Cape Peninsula, South Africa. S. Afr. J. Zool. 19: 97-104

Chapman, A. R. O. (1990). Effects of grazing, canopy cover and substratum type on the abundances of common species of seaweeds inhabiting littoral fringe tide pools. Botanica mar. 33: 319-326

Clark, B. C., Griffiths, C. L. (1990). Ecological energetics of mussels Choromytilus meridionalis under simulated intertidal rock pool conditions. J. exp. mar. Biol. Ecol. 137 $63-77$

Daniel, M. J., Boyden, C. R. (1975). Diurnal variations in physico-chemical conditions within intertidal rockpools. Fld Stud. 4: 161-176

Dayton, P. K. (1971). Competition, disturbance, and community organization: the provision and subsequent utilization of space in a rocky intertidal community. Ecol. Monogr. 41: $351-389$

Dethier, M. N. (1982). Pattern and process in tudepool algae: factors influencing seasonality and distribution. Botanica mar. 25: 55-66 
Dethier, M. N. (1984). Disturbance and recovery in intertidal pools: maintenance of mosaic patterns. Ecol. Monogr. 54: $99-118$

Droop, M. R. (1953). On the ecology of flagellates from some brackish and fresh water rockpools of Finland. Acta bot. fenn. 51: $1-52$

Fairweather, P. G., Underwood, A. J. (1991). Experimental removals of a rocky intertidal predator: variations within two habitats in the effects on prey. J. exp. mar. Biol. Ecol. 154: $29-75$

Femino, R. J., Mathieson, A. C. (1980). Investigations of New England marine algae IV. The ecology and seasonal succession of tide pool algae at Bald Head Cliff, York, Maine, USA. Botanica mar 23: 319-332

Field, J. G., Clarke, K. R., Warwick, R. M. (1982). A practical strategy for analysing multispecies distribution patterns. Mar. Ecol. Prog. Ser. 8: 37-52

Fraser, J. H. (1936). The distribution of rock pool copepoda according to tidal level. J. Anim. Ecol. 5: 1936

Ganning, B. (1971). Studies of chemical, physical and biological conditions in Swedish rockpool ecosystems. Ophelia 9 : $51-105$

Goss-Custard, S., Jones, J., Kitching, J. A., Norton, T. A. (1979). Tidepools of Carrigathorna and Barloge Creek. Phil. Trans. R. Soc. Lond. B. 287: 1-44

Green, J. M. (1971). Local distribution of Oligocottus maculosus Girard and other tidepool cottids of the west coast of Vancouver Island, British Columbia. Can. J. Zool. 49, $1111-1128$

Gustavsson, U. (1972). A proposal for a classification of marine rockpools on the Swedish west coast. Botanica mar. 15: 210-214

Huggett, J., Griffiths, C. L. (1986). Some relationships between elevation, physico-chemical variables and biota of intertidal rock pools. Mar. Ecol. Prog. Ser. 29: 189-197

Janke, K. (1990). Biological interactions and their role in community structure in the rocky intertidal of Helgoland (German Bight, North Sea). Helgoländer Meeresunters. 44 219-263

Johnson, D. S., Skutch, A. F. (1928). Littoral vegetation on a headland of Mt. Desert Island, Maine. II. Tide-pools and the environment and classification of submersible plant communities. Ecology 9:307-338

Kleinbaum, D. G., Kupper, L. L., Muller, K. E. (1988). Applied regression analysis and other multivariable methods. PWS-KENT Publ. Co., Boston

Kooistra, W. H. C. F., Joosten, A. M. T., van den Hoek, C. (1989). Zonation patterns in intertidal pools and their possible causes: a multivariate approach. Botanica mar. 32 $9-26$

Littler, M. M. (1980). Morphological form and photosynthetic performances of marine macroalgae: tests of a functional/ form hypothesis. Botanica mar. 22: 161-165

Littler, M. M., Littler, D. S. (1980). The evolution of thallus form and survival strategies in benthic marine macroalgae: field and laboratory tests of a functional form model. Am. Nat. 116: 25-44

Littler, M. M., Littler, D. S. (1984). Relationships between macroalgal functional form groups and substrata stability in a subtropical rocky-intertidal system. J. exp. mar. Biol. Ecol. 74: 13-34

Lubchenco, J. (1982). Effects of grazers and algal competitors on fucoid colonization in tide pools. J. Phycol. 18: 544-550

Lubchenco, J., Menge, B. A. (1978). Community development and persistence in a low rocky intertidal zone. Ecol Monogr. 48: 67-94
Marsh, B., Crowe, T. M., Siegfried, W. R. (1978). Species richness and abundance of clinid fish (Teleostei; Clinidae) in intertidal rockpools. Zool. Afr. 13: 283-291

McCook, L. J., Chapman, A. R. O. (1991). Community succession following massive ice-scour on an exposed rocky shore: effects of Fucus canopy algae and of mussels during late succession. J. exp. mar. Biol. Ecol. 154: 137-169

Metaxas, A., Scheibling. R. E. (1993). Community structure and organization of tidepools. Mar Ecol. Prog. Ser. 98 $187-198$

Minchinton, T E. (1989). Factors influencing settlement and survival of the barnacle, Semibalanus balanoides (L.), in a developing rocky intertidal community in Nova Scotia, Canada. M.Sc. thesis, Dalhousie University

Parker, T., Chapman, A. R. O. (in press). Separating the grazing effects of periwinkles and amphipods on a seaweed community dominated by Fucus distichus. Ophelia

Parker, T., Johnson, C., Chapman, A. R. O. (1993). Gammarid amphipods and littorinid snails have significant but different effects on algal succession in littoral fringe pools Ophelia 38: 69-88

Parsons, T. R., Maita, Y., Lalli, C. M. (1984). A manual of chemical and biological methods for seawater analysis. Pergamon Press, Oxford

Pedersen, E. (1991). Population genetics of Mytilus from a developing intertidal community in Nova Scotia, Canada. M.Sc thesis, Dalhousie University

Pielou, E. C. (1969). An introduction to mathematical ecology Wiley-Interscience, New York

Sokal, R. R., Rohlf, F. J. (1981). Biometry. W. H. Freeman and Company, New York

Steneck, R. S., Dethier, M. N. (in press). A functional group approach to the structure of algal-dominated communities. Oikos

Stephenson, T A., Stephenson, A. (1950). Life between tidemarks in North America. I. The Florida Keys. J. Ecol. 38 $354-402$

Stephenson, T A., Stephenson, A. (1952). Life between tidemarks in North America. II. Northern Florida and the Carolinas. J. Ecol. 40: 1-49

Stephenson, T A., Stephenson, A. (1954a). Life between tide-marks in North America. IIIA. Nova Scotia and Prince Edward Island: description of the region. J. Ecol 42: $14-45$

Stephenson, T. A., Stephenson, A. (1954 b). Life between tidemarks in North America. IIIB. Nova Scotia and Prince Edward Island: the geographical features of the region. J. Ecol. 42: 46-70

Stephenson, T A., Zoond, A., Eyre, J (1934). The liberation and utilisation of oxygen by the population of rock-pools. J. exp. Biol. 11: 162-172

Sze, P. (1982). Distributions of macroalgae in tidepools on the New England coast (USA) Botanica mar. 25: 269-276

Underwood, A. J. (1981). Structure of the rocky intertidal community in New South Wales: patterns of vertical distribution and seasonal changes. J. exp. mar. Biol. Ecol. 51 $57-85$

Wilkinson, L. (1989). SYSTAT: the system for statistics. SYSTAT Inc., Evanston, IL

Wolfe, J. M., Harlin, M. M. (1988a). Tidepools in southern Rhode Island, U.S.A. I. Distribution and seasonality of macroalgae. Botanica mar. 31: 525-536

Wolfe, J. M., Harlin, M. M. (1988b). Tidepools in southern Rhode Island, U.S.A. II. Species diversity and similarity analysis of macroalgal communities. Botanica mar. 31 $537-546$

Manuscript first received: August 9, 1993

Revised version accepted: November 16, 1993 